\title{
Nematode Parasites and Associates of Ants: Past and Present
}

\author{
George Poinar Jr. \\ Department of Zoology, Oregon State University, Corvallis, OR 97331, USA \\ Correspondence should be addressed to George Poinar Jr., poinarg@science.oregonstate.edu
}

Received 14 August 2011; Accepted 9 October 2011

Academic Editor: Jean Paul Lachaud

Copyright ( $) 2012$ George Poinar Jr. This is an open access article distributed under the Creative Commons Attribution License, which permits unrestricted use, distribution, and reproduction in any medium, provided the original work is properly cited.

\begin{abstract}
Ants can serve as developmental, definitive, intermediate, or carrier hosts of a variety of nematodes. Parasitic ant nematodes include members of the families Mermithidae, Tetradonematidae, Allantonematidae, Seuratidae, Physalopteridae, Steinernematidae, and Heterorhabditidae. Those nematodes that are phoretically associated with ants, internally or externally, are represented by the Rhabditidae, Diplogastridae, and Panagrolaimidae. Fossils of mermithids, tetradonematids, allantonematids, and diplogastrids associated with ants show the evolutionary history of these relationships, some of which date back to the Eocene (40 mya).
\end{abstract}

\section{Introduction}

Nematodes are one of the most abundant groups of animals known. Studies on their evolutionary history suggest that they probably arose in the Precambrian, which explains their wide abundance today in the terrestrial and marine environments. While only some 20,000 have been described, their species diversity has been estimated to be as high as 10 million [1].

One would assume that with their strict housekeeping habits, ants would not tolerate nematodes in or around their nests and would quickly dispose of any nest mates that might have become infected. However nematodes have been able to use some astonishingly sophisticated tactics to successfully parasitize these social insects. The present work covers the systematics, life history, pathology, and records of all described extant and fossil nematodes associated with formicids. This includes representatives of the nematode families Mermithidae, Tetradonematidae, Allantonematidae, Seuratidae, Physalopteridae, Steinernematidae, Heterorhabditidae, Rhabditidae, Diplogastridae, and Panagrolaimidae. Fossil records of mermithids, tetradonematids, allantonematids, and diplogastrids associated with ants reveal the evolutionary history of these associations, some of which date back 40 million years.

\section{Mermithidae}

The family Mermithidae includes parasites of invertebrates, especially insects. Because of their large size, mermithids are easily detected in ants upon dissection (Figure 1) or as they leave their hosts (Figure 2). Most mermithid species, including those that attack ants, parasitize only a specific host species, genus, or family while others can infect representatives of several insect orders. Mermithids that attack aquatic insects, such as midges (Chironomidae, Ceratopogonidae) and mosquitoes (Culicidae), have a direct life cycle. Direct life cycles occur when, after growth and development is completed in the host, the mermithid emerges, molts to the adult stage, mates, and oviposits in the host's environment. The infective stage mermithid emerges from the egg, actively locates and enters a host, and initiates development in the hemocoel.

Some mermithids have an indirect life cycle, which is more complicated but allows hosts to be parasitized in environments hostile to nematodes. In an indirect cycle, the mermithid emerges from the host, molts, mates, and oviposits in the environment. But instead of emerging from the egg to search for a developmental host, the infective stage remains in the egg, waiting to be ingested by an invertebrate that serves as a paratenic host. When mermithid eggs are ingested by a paratenic host, the hatching infective stage penetrates the gut wall and enters the body cavity. But instead of developing, the mermithid encysts and enters a diapause. The encysted nematode can be carried through the different stages of host metamorphosis, but for its cycle to be completed, the paratenic host must be captured and fed to the brood of the developmental host. At the completion of the mermithids growth phase in the development host (like an ant), the latter is attracted to an aquatic or semiaquatic habitat favorable 


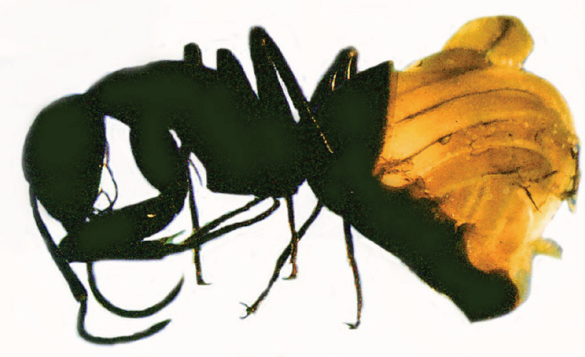

Figure 1: Mermithid exposed in the gaster of Camponotus sp. from the Sierra Nevada, California.

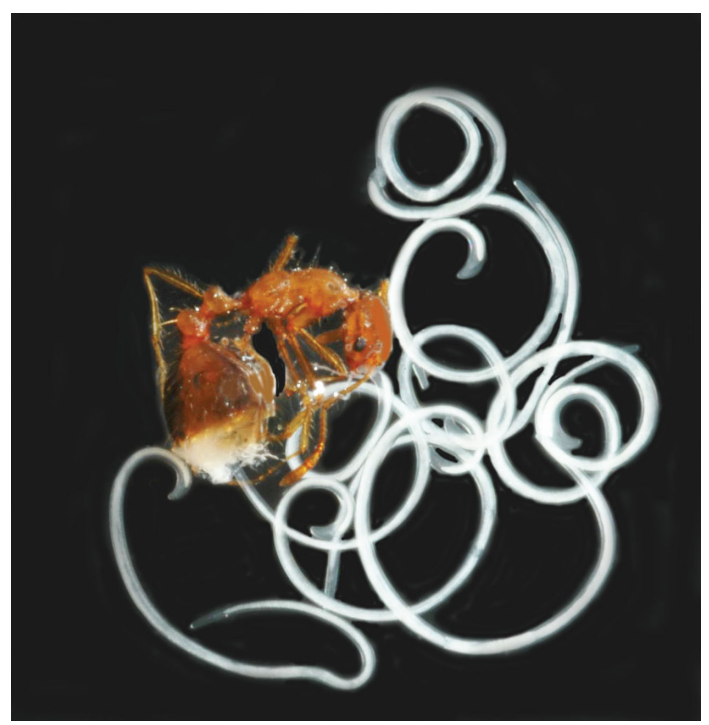

Figure 2: Parasitic juveniles of Allomermis solenopsi removed from the gaster of a fire ant worker. Photo courtesy of S. D. Porter, USDAARS.

to the nematode. This is when the mermithid exits, leaving the dying host behind. The developmental host is usually not only larger, but usually in a completely different taxonomic category and environment from the paratenic host. While the developmental host can live in a relatively dry habitat, the paratenic host usually inhabits an aquatic, semiaquatic, or damp biome. Also, both hosts can be widely separated taxonomically and may not even belong to the same phylum.

The first written account of a nematode parasite of ants was made by the Reverend William Gould in his 1747 book An account of English Ants (Table 1) [2].

The "white and long kind of worm, which is often met within their bodies" certainly refers to mermithid nematodes. For a number of years, mermithids were listed under "Filaria," "Gordius," or "Mermis," and that is why mermithid systematics can be confusing and why early names for Gould's ant mermithid included Gordius formicarum Diesing [3] and Filaria formicarum von Siebold [4].

The first described ant mermithid was Pheromermis myrmecophila from Lasius spp. [5]. However it was originally described in the genus "Mermis", then assigned to the genus
TABLe 1: Section from Gould [2] referring to the first reported instance of mermithid parasitism of ants.

Amongt other Incidents that tend to leffen
and deftroy Ant-Flies, it is obfervable that abun-
dance of them are demolifhed by a white and long
Kind of Worm, which is often met with in their
Bodies. You may frequently take three from the
Infides of the large, but feldommore than one from
a fmall Ant-Fly. Thefe Worms lie in a fpiral
Form, and fome of them may be extended Half
an Inch.

TABle 2: Mermithid nematodes described from ants.

\begin{tabular}{lcc}
\hline Mermithid & Host & Reference \\
\hline Agamomermis cephaloti & Cephalotes minutus & {$[11]$} \\
Agamomermis costaricensis & Odontomachus hastatus & {$[11]$} \\
Agamomermis ecitoni & Eciton burchellii & {$[11]$} \\
Allomermis solenopsi & Solenopsis invicta & {$[12]$} \\
Camponotimermis bifidus & Camponotus aethiops & {$[13]$} \\
Comanimermis clujensis & Formica fusca & {$[14]$} \\
& Camponotus aethiops & \\
${ }^{*}$ Heydenius formicinus & Prenolepis henschei & {$[15]$} \\
*Heydenius myrmecophila & Linepithema sp. & {$[11]$} \\
Meximermis ectatommi & Ectatomma ruidum & {$[11]$} \\
Pheromermis lasiusi & Lasius niger & {$[16]$} \\
Pheromermis myrmecophila & Lasius spp. & {$[5]$} \\
Pheromermis villosa & Lasius flavus, L. niger & {$[17]$} \\
\hline
\end{tabular}

${ }^{*}$ fossil.

Pheromermis [6], then moved to the genus Allomermis [7] and lastly to the genus Camponotimermis [8]. Its position in the genus Pheromermis was recently confirmed by Kaiser, who showed its similarity with the European ant mermithid, Pheromermis villosa [9]. Over the years, a large number of ant species have been reported parasitized by mermithids. A list of Holarctic parasitized ants was presented by Passera [10] and Neotropical parasitized ants by Poinar et al. [11]. A compilation of all described mermithids from ants is presented in Table 2.

Fossils, such as the postparasitic juvenile of Heydenius formicinus emerging from a male Prenolepis henschei (Figure 3) [15], as well as from a worker ant (Figure 4) in Baltic amber [1] show that ants have been parasitized by mermithids for at least 40 million years and probably much longer. The fossil record of Neotropical mermithid parasites of ants is represented by a parasitic juvenile of Heydenius myrmecophila adjacent to its ant host, Linepithema sp. in 2030-million-year-old Dominican amber (Figure 5) [11]. It is assumed that the traumatic events of the ant host entering the resin caused the mermithid to emerge prematurely from an opening in the gaster of the ant. 


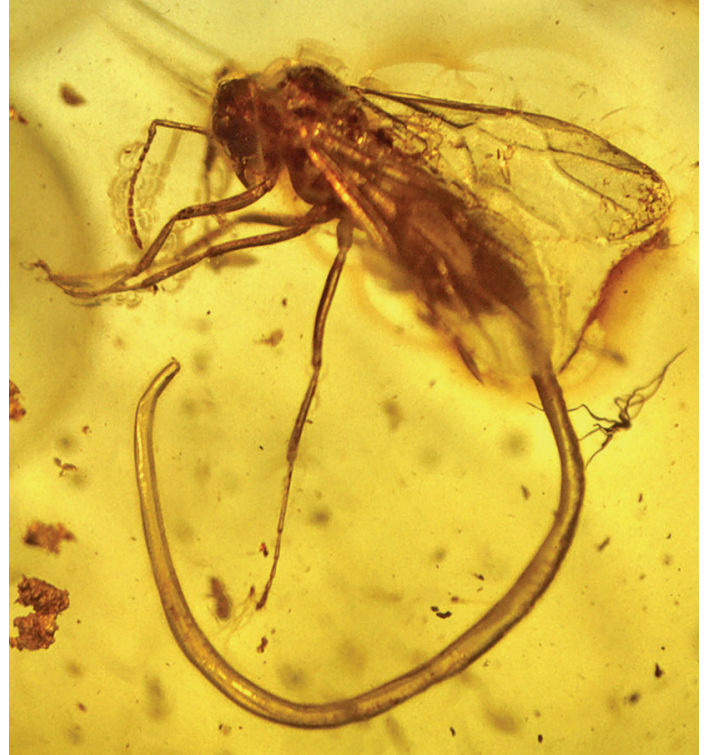

Figure 3: The fossil nematode, Heydenius formicinus, emerging from a male Prenolepis henschei in Baltic amber.

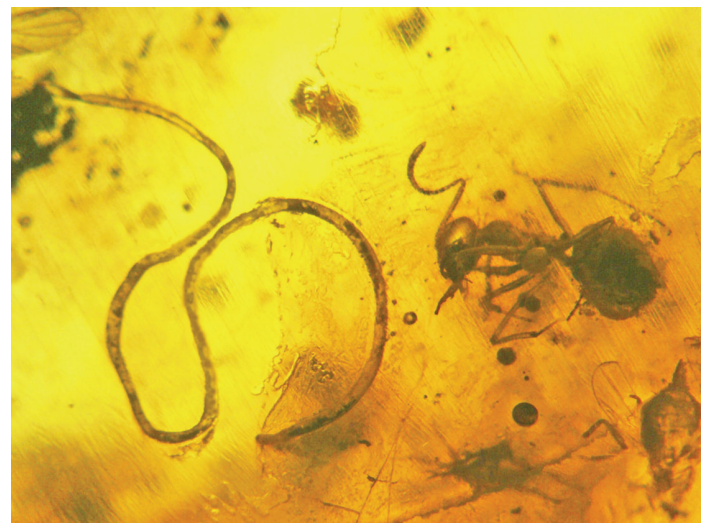

Figure 4: Heydenius formicinus adjacent to its worker ant host in Baltic amber.

Depending on the caste and length of time the mermithid is associated with its host, various degrees of host intercastes and abnormalities appear. Wheeler [18] was the first to provide an explanation for these phenomena by correlating the unusual morphological conditions with mermithid infections (Figure 6). Parasitized queen ants (mermithogynes) are shorter, have a smaller thorax (stenothoracy), reduced wings (brachyptery), enlarged abdomen (physogastry), and smaller head (microcephaly) than their uninfected counterparts. Parasitized worker ants (mermithergates or macroergates) often develop morphological features characteristic of queens and soldiers. Attacked male ants (mermithaners) have shorter wings but enlarged heads, eyes, and gasters. Infected soldiers (mermithostratiotes) have reduced heads, an ocellus, and changes in pilosity (Figure 7) [19-24].

The life cycle of most ant mermithids remains a mystery. Crawley and Baylis [5] assumed that P. myrmecophila has a direct cycle, where infection is brought about by the eclosing

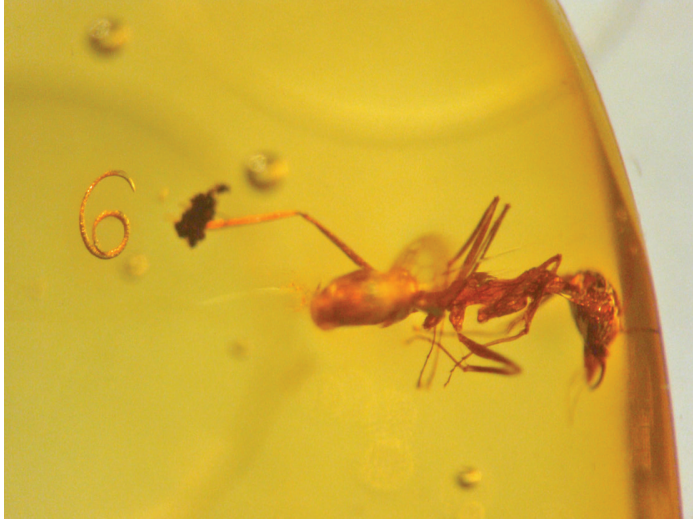

FIgure 5: Heydenius myrmecophila adjacent to its Linepithema ant host in Dominican amber.

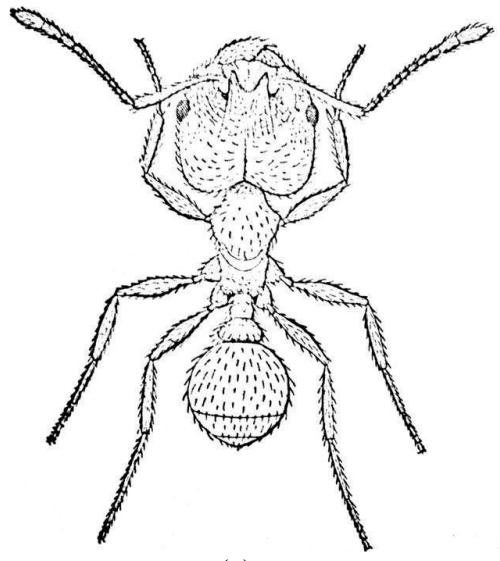

(a)

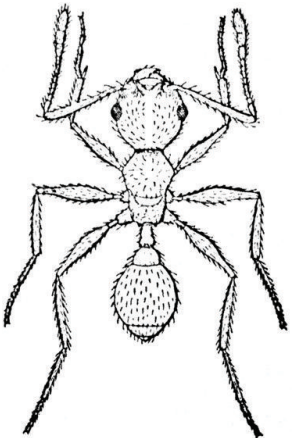

(b)

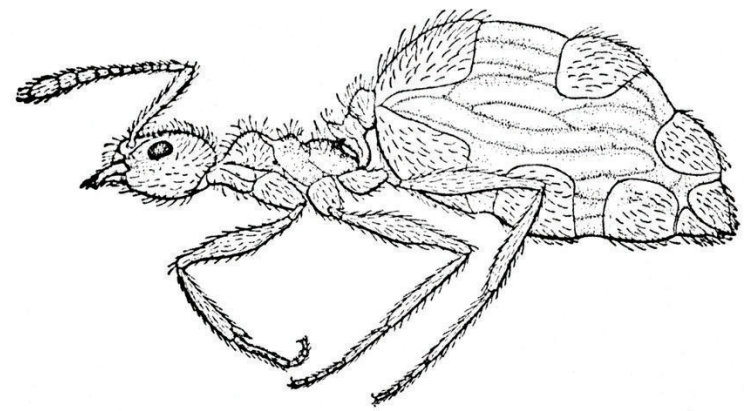

(c)

Figure 6: Plate (modified) of Pheidole dentata (referred to as $P$. commutata) from [18] showing the first evidence that mermithid nematodes could cause intercastes of ants. (a) Normal soldier; (b) normal worker; (c) parasitized worker (mermithergate).

preparasitic mermithid entering the ant host. When development is completed, the postparasitic juvenile emerges, molts to the adult stage in the ant's habitat, mates, oviposits and the cycle continues. However, no one has demonstrated a direct cycle for any mermithid parasite of ants. In 1934, Vandel [25] studied a mermithid parasite of Pheidole pallidula and realized that the infection must be initiated in the ant larva. He assumed that the nematodes were in the soil surrounding the ant colony so the infective stages could penetrate directly into 


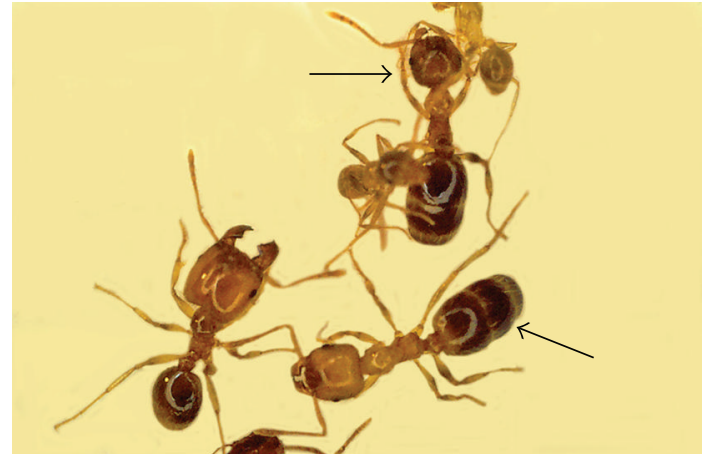

Figure 7: Two mermithid-infected soldiers (mermithostratiotes) (arrows) of Pheidole pallidula adjacent to smaller workers and an uninfected soldier (with large head). Note smaller heads on infected soldiers. Photo courtesy of Luc Passera.

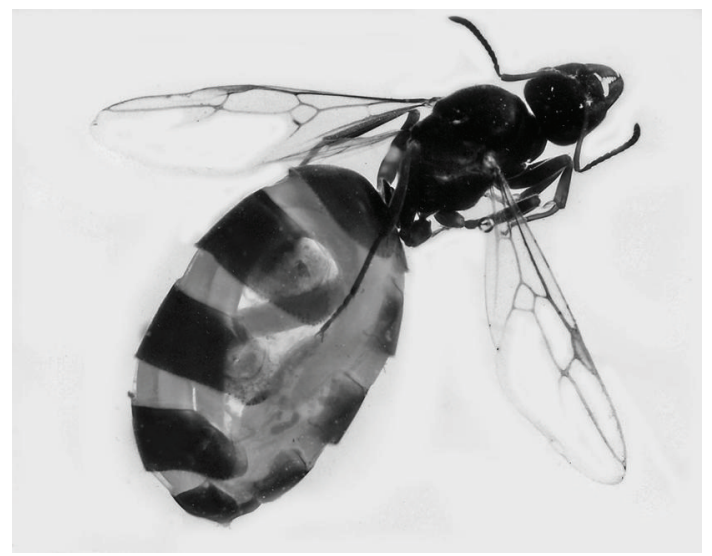

Figure 8: Pheromermis villosa in a carpenter ant from Holland.

the ant larva; however he was unable to confirm the infection process.

The first life cycle of an ant mermithid was achieved by Kaiser with the European Pheromermis villosa [17, 26] (Figure 8). Kaiser showed that P. villosa had an indirect cycle involving oligochaetes as paratenic hosts. Workers of Lasius spp. collecting protein for the brood capture oligochaetes containing the infective stages of $P$. villosa and, unknowingly, feed them to the developing larvae. At this point, the nematode becomes active, penetrates into the ant larva's hemocoel, and initiates development. It was a significant discovery and raises the question whether all mermithid infections of ants have indirect life cycles. Other possible paratenic hosts for Pheromermis could be small aquatic insects that ingest mermithid eggs from the bottom debris of seepage areas or the edges of other water sources. The wasp parasite, Pheromermis pachysoma [6], also has an indirect cycle and uses caddis flies as paratenic hosts, which the eusocial wasps (Vespidae) feed to their brood [27].

Thus far, seven genera of mermithids are known to infect ants, namely, Agamomermis, Allomermis, Camponotimermis, Comanimermis, Heydenius, Meximermis, and Pheromermis (Table 2). All of the ant hosts of these mermithids feed their brood animal protein (in contrast to other genera, such as the leaf cutting ants), and this behavior suggests they have an indirect life cycle involving a paratenic host. The two genera, Agamomermis and Heydenius, are collective group genera for immature extant and fossil mermithids, respectively [1].

There are some morphological and behavioral patterns that characterize mermithids with indirect cycles. They normally have smaller eggs with thicker shells than the eggs of direct development soil or freshwater mermithids. Also their eggs are completely embryonated when laid. Finally, the deposited eggs will not hatch in the environment even though the enclosed parasitic juvenile is fully developed. Hatching only occurs when a potential invertebrate paratenic host ingests the eggs. The eggs of Pheromermis spp. are small, numerous, fully embryonated when laid and do not hatch in the environment. Fully embryonated eggs ensure that the infective stages are ready to enter paratenic hosts as soon as they are ingested $[6,17]$.

The ant mermithid, Allomermis solenopsi [12], possess an unusual morphological feature on the mature eggs that could play a crucial role in its life cycle. The surface of the eggs is covered with elongate, erect, spiny adhesive processes. How these function in the life cycle is unknown, but the related species, A. trichotopson, possesses similar structures [28]. Since A. solenopsi parasitizes the fire ant, Solenopsis invicta in Brazil (Figure 2), the related A. trichotopson, whose host is unknown, may infect Solenopsis geminata in Jamaica. Could these egg processes somehow be connected with parasitism of Solenopsis spp.?

Can mermithids be manipulated to control ants? Aside from killing the ant host upon emergence, mermithids drain the host of food, reduce the flight muscles and fat body, and cause morphological modifications as mentioned above [ 9 , 17, 24, 26]. Since mermithid-infected Solenopsis has reduced reproductive organs and die shortly after the nematodes emerge [11, 12, 29], it has potential as a biological control agent. However, if the cycle is always indirect as shown for $P$. villosa, it would be very difficult to artificially infect the ant brood. It would be necessary to first infect the paratenic host and then supply large numbers of these infected invertebrates to worker ants for transport back to the nest. Working with a mermithid that has a direct cycle would be easier; however there is still the problem of raising and disseminating the nematodes.

\section{Tetradonematidae}

The tetradonematids are a diverse group of nematodes that have traditionally been aligned with the Mermithidae. However, aside from some distinctive morphological characters, female tetradonematids normally mature, mate, and produce eggs within the host, which does not occur with mermithids. Two tetradonematids have been described from extant ants. Tetradonema solenopsis is a parasite of the red imported fire ant, Solenopsis invicta, in Brazil [30, 31]. Very little is known about this nematode aside from the scant description showing that females contained eggs and worker infection levels reached $12.5 \%$. Parasitized ants that succumbed to the infections could be recognized by their slightly enlarged gaster with scallop-appearing dorsal sclerites. 


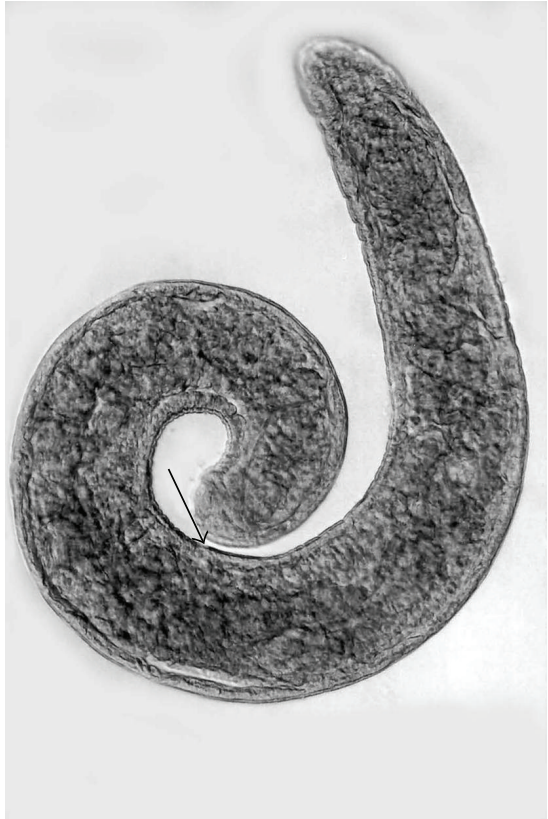

FIgURE 9: Mature female of Myrmeconema neotropicum in the early stages of egg production removed from a pupa of Cephalotes atratus. Arrow shows position of vulva.

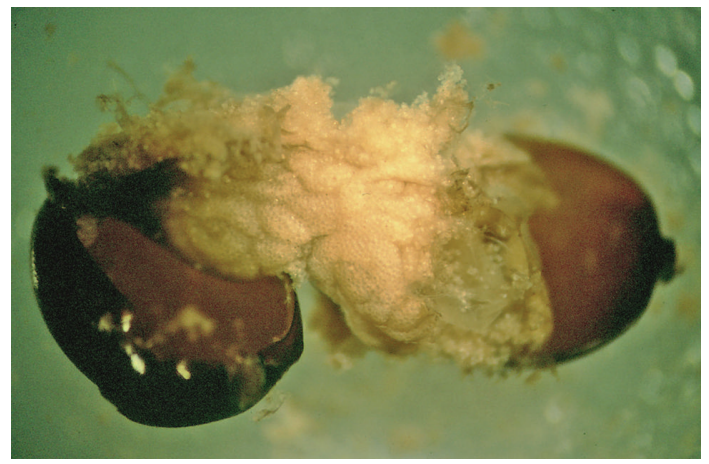

Figure 10: Mature females of Myrmeconema neotropicum packed with eggs in the gaster of a Cephalotes atratus worker in Peru.

The second tetradonematid from extant ants is Myrmeconema neotropicum from Cephalotes atratus in Peru and Panama [32]. Myrmeconema is the only nematode that causes its ant host to radically change color (from black to red), which is crucial for completion of its life cycle [33]. This color change was a mystery for early taxonomists and the variety Cephalotes atratus var. rufiventris was erected solely on the basis of its red abdomen, which was later shown to be the result of Myrmeconema infections [32].

Developing females of $M$. neotropicum occur in ant pupae (Figure 9) but do not produce masses of eggs until they are carried into the adult ant (Figure 10). As the females deteriorate, eggs are released into the ant's hemocoel (Figure 11). At this stage of development, the gasters of the infected worker ants turn from black to red and are held high in the air (Figure 12) [33]. Birds mistake the red gasters for fruits and the nematode eggs are passed through the birds' digestive

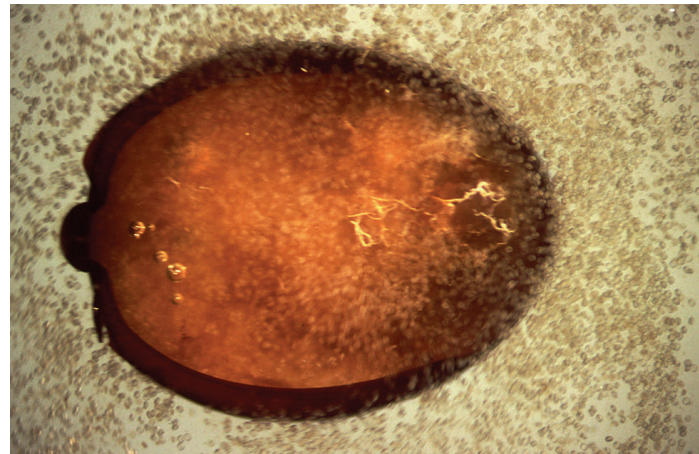

FIgURE 11: Eggs of Myrmeconema neotropicum released from the gaster of an infected Cephalotes atratus worker in Peru.

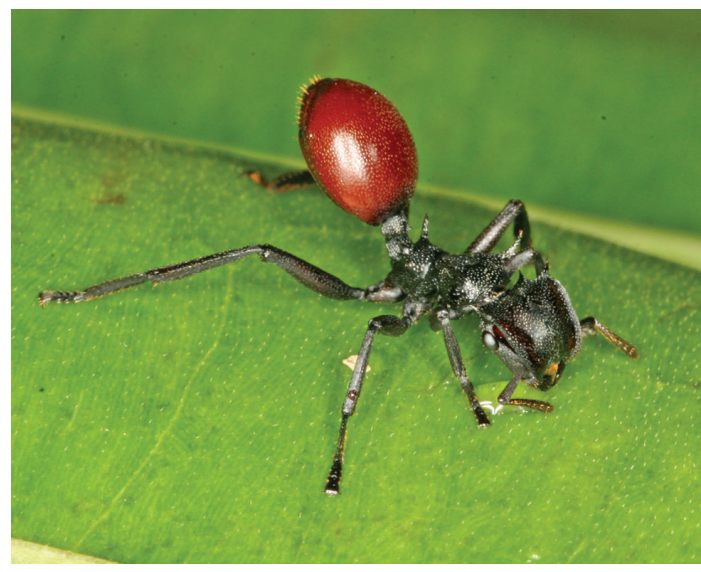

FIGURE 12: Worker of Cephalotes atratus infected with Myrmeconema neotropicum. The raised, red abdomen occurs when the nematode eggs are infective and ready for transport by birds. Photo courtesy of Stephen P. Yanoviak.

system and end up in the droppings, which are deposited on leaves and branches. Cephalotes workers collect and feed the infested excreta to their brood, which is how the larvae become infected [33].

Aside from their red gasters, parasitized ants are smaller with reduced head widths. They are sluggish, clumsy, generally less aggressive, and about $40 \%$ heavier than nonparasitized workers. They do not bite when handled, and their alarm/defense pheromone supply is significantly reduced or absent.

Myrmeconema is probably widely distributed throughout the Neotropics since this association has been in existence for some 20-30 million years. The fossil worker ant, Cephalotes serratus in Dominican amber, is surrounded by the eggs of Myrmeconema antiqua (Figure 13) [1]. The ant has a hole in its abdomen that quite possibly was made by a bird. Many of the eggs, which closely resemble those of M. neotropicum in size and shape, contain fully developed juveniles (Figure 14). All indications suggest that $M$. antiqua had a similar life history to the extant M. neotropicum and involved bird carriers. 


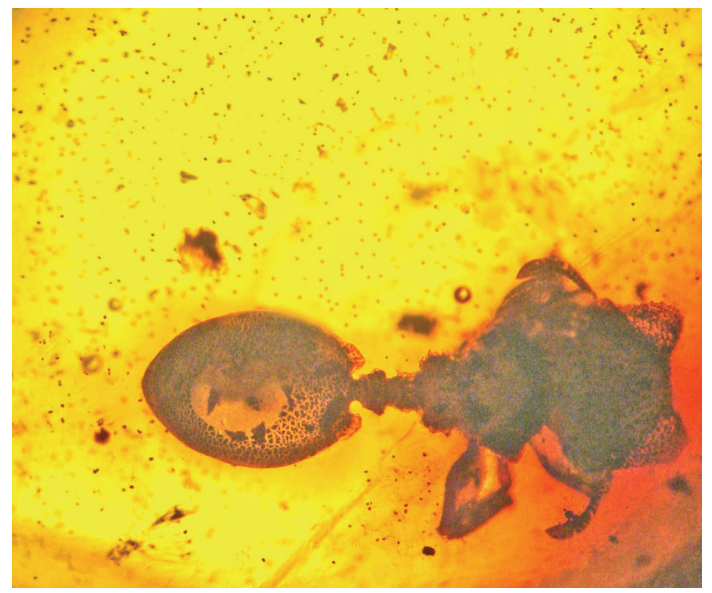

Figure 13: Worker of Cephalotes serratus infected with Myrmeconema antiqua in Dominican amber. Note microscopic eggs widely distributed in the amber that were released from a hole in the ant's gaster.

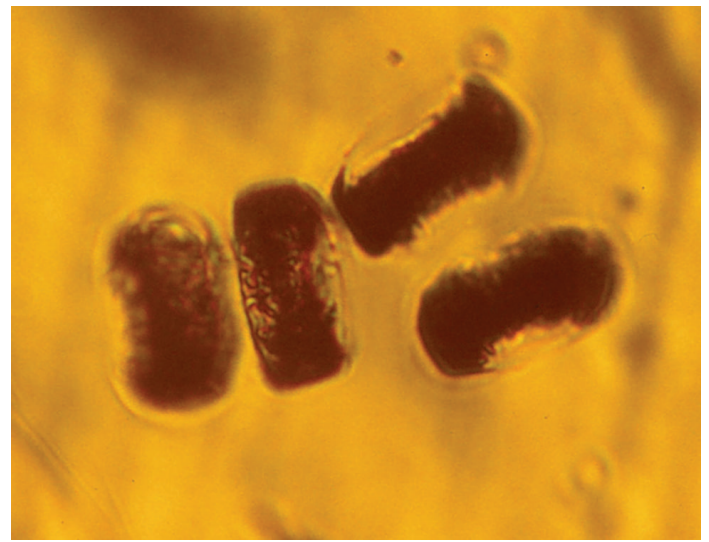

FIGURE 14: Detail of eggs of Myrmeconema antiqua in various stages of development in Dominican amber.

\section{Allantonematidae}

It is curious why so few cases of allantonematid infections have been reported in ants. Since ants are probably one of the most investigated insect groups, is the absence of tylenchid parasitism due to a lack of observations or its rarity? The first and only described allantonematid parasite of extant ants is Formicitylenchus oregonensis that was parasitizing a queen Camponotus ant in Western Oregon, USA [34]. The queen had already chewed off her wings and appeared to be searching for a nesting site. There was a single large parasitic female (Figure 15) and 120 third-stage juvenile nematodes in the ant's gaster. The third-stage juveniles exited through the ants reproductive and digestive tracts and molted twice to reach the adult stage. The enlarged pharyngeal glands in the free-living females suggest that they penetrate the cuticle to enter the body cavity of the host, probably ant larvae. Although the complete life cycle is unknown, the nematodes are clearly distributed by infected queen ants. The gonads of the infected ant were greatly reduced, and her eggs were

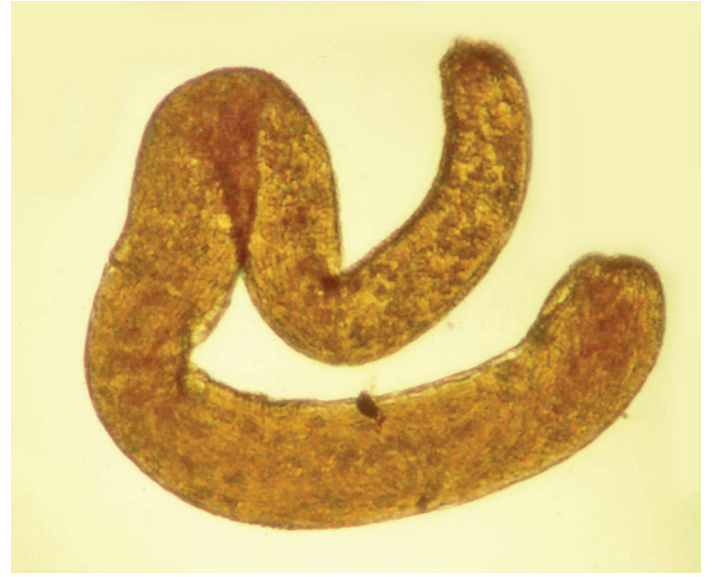

Figure 15: Female of the allantonematid Formicitylenchus oregonensis removed from the body cavity of Camponotus vicinus in Oregon, USA.

abnormal. Since carpenter ants can be damaging to structures, $F$. oregonensis can be considered as a potential biological control agent.

Since the original report of this parasite, the present author recovered a worker carpenter ant also infected with $F$. oregonensis, thus indicating that Formicitylenchus is probably restricted to ant hosts, especially members of the genus Camponotus. Formicitylenchus shows a close relationship with the allantonematid beetle parasite, Metaparasitylenchus [34]. It is possible that their last common ancestor parasitized beetles and the host shift from arboreal beetles to arboreal ants occurred during the anagenesis of Formicitylenchus. The close physical association between wood-boring beetles and Camponotus ants may be significant. Rogers [35] commented that "...the potential parasite would be expected to find its hosts in organisms which occupy the same niche largely independent of their phylogenetic position. In fact the specificity of many parasites is based on the ecological relationship of the hosts, especially in groups which have only recently become parasitic."

Another reason that allantonematid parasitism of ants may be more widespread than presumed is the discovery of juveniles of a fossil allantonematid, Palaeoallantonema cephalotae, in the ant, Cephalotes serratus, in Dominican amber [1] (Figure 16). Just before this fossil was discovered, Steven Yanoviak submitted an extant worker of Cephalotes christopherseni from Peru that was also infected with an allatonematid. The parasitic female (Figure 17) of this still undescribed species and the developing juveniles inside her body (Figure 18) show features typical of the family.

\section{Seuratidae}

The discovery of adults of Rabbium paradoxus [36] inside the gaster of worker Camponotus castaneus in Florida (Figure 19) was a surprise since all known nematodes of the Seuratidae are heteroxenous and develop to the adult stage in the digestive tract of vertebrates [37]. However, in $R$. paradoxus, the 


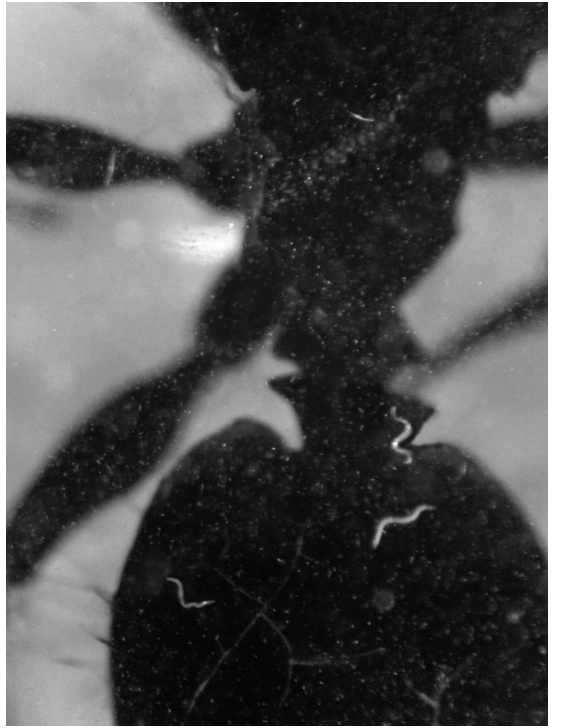

Figure 16: Three juveniles of the allantonematid, Palaeoallantonema cephalotae, that emerged from a worker Cephalotes ant in Dominican amber.

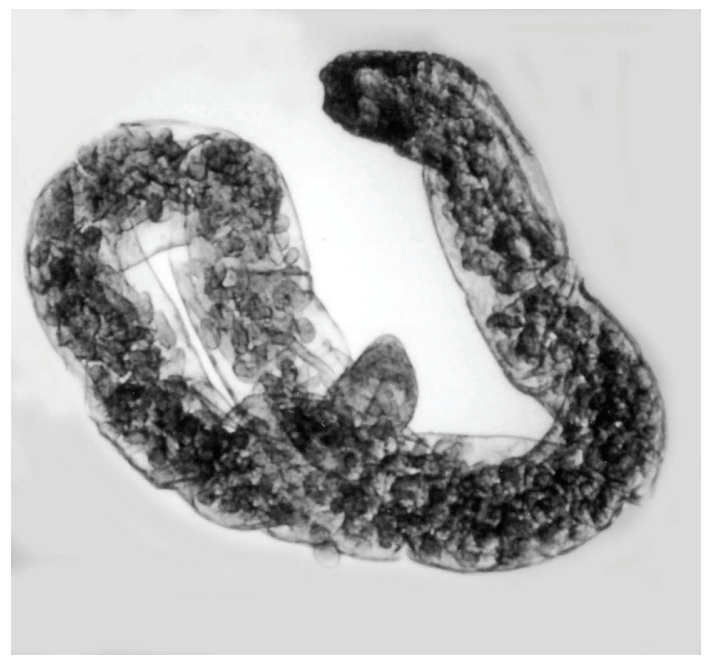

FIgURE 17: Parasitic female of an undescribed allantonematid from workers of Cephalotes christopherseni in Peru.

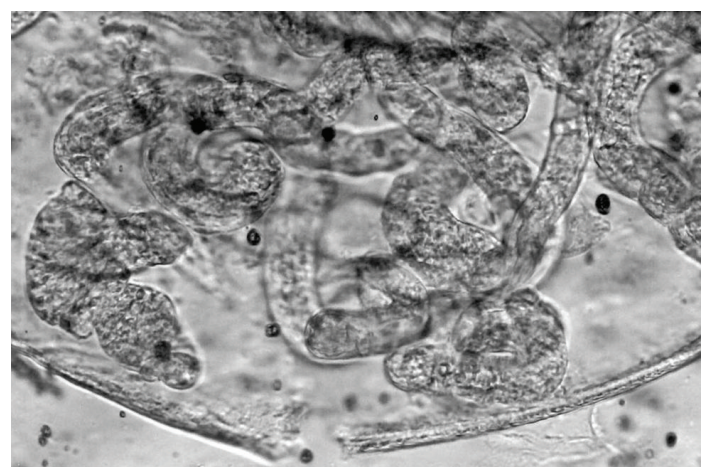

Figure 18: Juveniles developing inside the body of the female allantonematid shown in Figure 17.

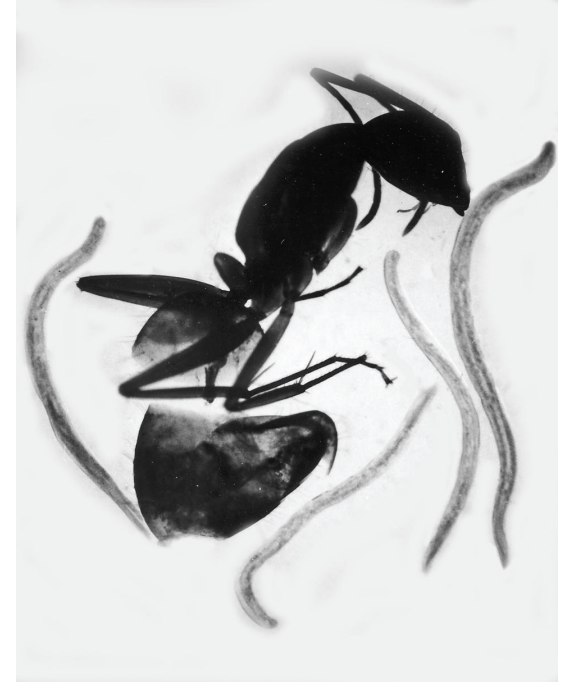

FIGURE 19: Adults of Rabbium paradoxus adjacent to their ant host, Camponotus castaneus, in Florida.

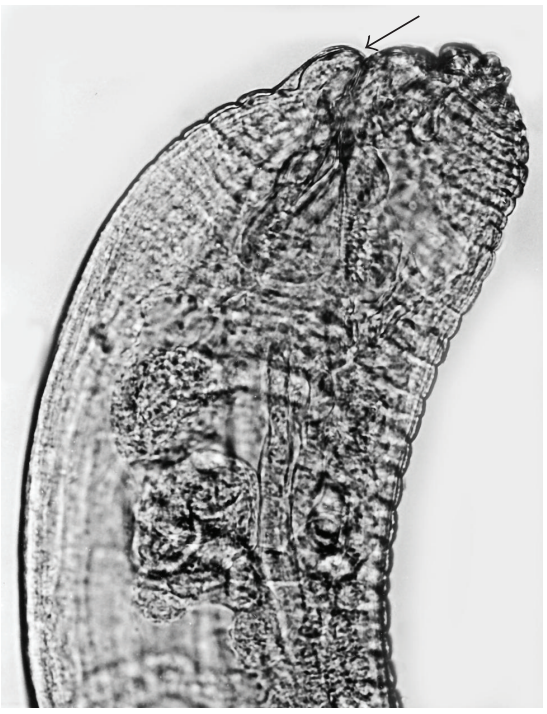

Figure 20: Head of a female of Rabbium paradoxus. Arrow shows anteriorly located vulva.

vertebrate host is obviously not required for adult development. The females of $R$. paradoxus have an anteriorly placed vulva (Figure 20), and the eggs embryonate inside the uterus (Figure 21). Since the other member of the genus, $R$. caballeroi, occurs in the gut of lizards in the Bahamas [38], it is likely that $R$. paradoxus originally had (or still has) a lizard definitive host. If the complete life cycle occurs just in ants, then C. castaneus would serve as both intermediate and definitive hosts. C. castaneus is a generalist feeder and will ingest vertebrate feces so it could acquire nematode eggs from lizard droppings. Parasitized worker ants had swollen gasters and showed unusual behavior by foraging during the day instead at night. This would make them easily captured by vertebrate predators. 


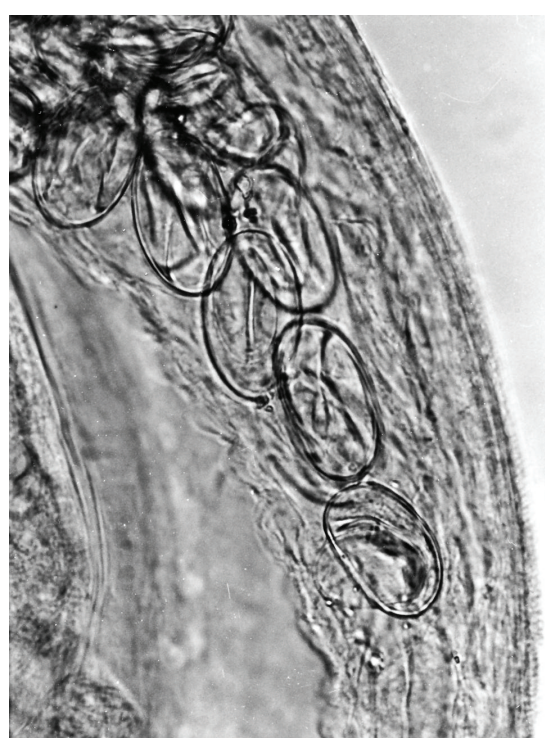

FIGURE 21: Embryonated eggs in the uterus of Rabbium paradoxus.

The original life cycle of $R$. paradoxus may have been similar to that of the seuratoid Skrjabinelazia galliardi, a parasite of sphaerodactyline lizards in Brazil [37]. The female nematodes living in the gut of the lizard produce eggs that are passed out and ingested by insects. These eggs hatch in the insect gut and the juveniles enter the body cavity without further development. Growth is resumed when the insect intermediate hosts are eaten by lizards [38]. Unfortunately, the complete life cycle of $R$. paradoxus remains a mystery, but its precocious development is quite interesting.

\section{Physalopteridae}

There are few reports of heteroxenous nematodes utilizing ants as intermediate hosts, that is, hosts where the nematodes develop only to the third-stage infective juveniles. Maturity to the adult stages occurs when the intermediate host is eaten by a vertebrate definitive host. One such nematode is the physalopterid, Skrjabinoptera phrynosoma that lives in the stomach of the Texas horned lizard, Phrynosoma cornutum, and uses the harvester ant, Pogonomyrmex barbatus, as an intermediate hosts [39]. However instead of depositing isolated eggs that would pass from the lizard, the gravid nematodes die with the retained eggs enclosed in thick walled capsules. The females with their enclosed eggs pass out of the lizard and are collected by worker ants that feed them to their brood. The nematode eggs hatch in the gut of the ant larvae and the juveniles enter the fat body, where they develop only to the third stage. These juveniles are carried through the pupal and into the adult stage of the ant, where they eventually reside in membranous capsules. The nematodes complete their development to the adult stage when infected ants are eaten by the lizards. Worker ants with more than 10 nematodes were still active but had enlarged, lighter colored gasters. The interesting, pivotal stage in this life cycle is the attractiveness of the dead, egg-laden female nematodes to worker ants.

\section{Rhabditidae, Diplogastridae, and Panagrolaimidae}

This category includes juvenile nematodes living in the postpharyngeal glands of ants (internal phoresis) or being carried on the outside surface of ants (external phoresis) (Table 3 ). While these might not be considered parasites, in some instances where the association has been examined critically [40] damage has been inflicted on the ant's postpharyngeal glands and some of the nematodes increased in size during their stay in this location. Thus at most, they could be considered weak parasites. If they break through the glands and introduce microbes into the body cavity of the ant, they could even be regarded as pathogenic. However the latter scenario has not been documented.

Most of the nematodes in the postpharyngeal glands are dauer juveniles of free-living microbotrophs living in the ant's environment. The dauers enter the glands when external conditions become unsuitable (low humidity or diminished food supply). These resistant dauer juveniles can survive for relatively long periods. The nematodes may leave the glands when the environment is more suitable (moist with associated microbes), if the ant dies and the dauer initiates development within the decomposing ant, or when the nematodes are transferred from ant to ant during trophallaxis.

Janet [43] was the first to discover postpharyngeal rhabditids (Oscheius dolichurus) in Lasius flavus and Formica ru$f a$ in France. Wahab [42] was the first to systematically study these associations in the ant genera Lasius, Formica, Tetramorium, and Myrmica in Germany (Table 3). More recently Köhler [41] examined nematodes in the heads of ants collected from sap fluxes and rotten wood on trees in Germany. The most common ant that visited these fluxes was Lasius brunneus and, from a total of 262 workers collected, $43.5 \%$ carried nematodes, with Koerneria histophora being the most common associate. While most ants carried a single nematode, numbers occasionally reached up to 85 dauers per ant. Köhler [41] also found diplogastrid dauers in 4 males and a queen of L. brunneus. The infection rate of ants associated with L. brunneus workers varied depending on the weather cycle. There were more nematodes in ants during the dry period in August than during the rainy months of April and May. Also important in determining the rate of nematodes being carried by the ants was the location of the nests. Rates of infestation by nematodes in L. brunneus were much higher when the ants were collected from sap fluxes and rotten wood [41], than were collected from under stones and leaf litter [42].

Köhler [41] was able to infest ants by placing them in a Petri dish with rotten wood containing waving dauer stages. Both Wahab [42] and Köhler [41] provided evidence that the dauers can be transmitted from ant to ant via trophallaxis, which was supported in part by the experiments of Naarmann [53] showing that Formica ants mix food with secretions from the postpharyngeal gland before regurgitating it to nest mates. These ant-dauer associations probably occur worldwide since Markin and McCoy [40] reported Diploscapter lycostoma in the postpharyngeal glands of the Argentine Ant, Linepithema humile in California and Nickle \& Ayre 
TABLE 3: Juvenile nematodes of Rhabditida and Tylenchina associated with ants.

\begin{tabular}{|c|c|c|c|}
\hline Nematode & Family & Host & Reference \\
\hline Diplogasteroides spengelii & Diplogastridae & Lasius brunneus & {$[41]$} \\
\hline Diploscapter lycostoma & Rhabditidae & Formica spp., Lasius spp. & {$[42]$} \\
\hline “ & “ & Myrmica rugulosa & {$[42]$} \\
\hline “ & “ & Linepithema humile & {$[40]$} \\
\hline $\begin{array}{l}\text { *Formicodiplogaster } \\
\text { myrmenema }\end{array}$ & Diplogastridae & Azteca alpha & {$[1]$} \\
\hline Halicephalobus similigaster & Panagrolaimidae & Lasius brunneus & {$[41]$} \\
\hline Koerneria histophora & Diplogastridae & Lasius spp. & {$[42]$} \\
\hline “ & “ & Lasius brunneus & [41] \\
\hline Oscheius dolichurus & Rhabditidae & Formica rufa, & {$[42,43]$} \\
\hline “ & “ & Lasius flavus & {$[42,43]$} \\
\hline “ & “ & Tetramorium caespitum & {$[42]$} \\
\hline “ & “ & Camponotus herculeanus & {$[44]$} \\
\hline “ & “ & Lasius claviger & {$[44]$} \\
\hline “ & “ & Lasius brunneus & {$[41]$} \\
\hline Pristionchus lheritieri & Diplogastridae & Formica rufa, Lasius spp. & {$[42]$} \\
\hline$*$ Unknown & " & Azteca spp. & {$[1]$} \\
\hline Unknown & “ & Formica obscuriventris & $\begin{array}{l}\text { Present work } \\
\text { (Figure 22) }\end{array}$ \\
\hline
\end{tabular}

${ }^{*}$ Fossil.

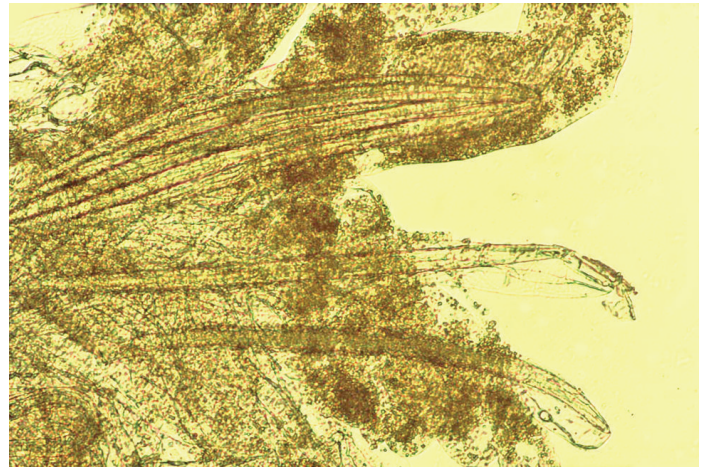

Figure 22: Dauer juveniles of a diplogastrid in the postpharyngeal glands of Formica obscuriventris clivia from Oregon.

[44] found Oscheius dolichurus in the head glands of Camponotus herculeanus and Lasius claviger in Ontario, Canada. The author has also found dauer diplogastrids in the postpharyngeal glands of workers of Formica obscuriventris in Oregon (Figure 22).

The association between dauer nematodes and ants is at least 20-30 million years old. Evidence for this is the discovery of dauer juveniles of the fossil diplogastrid, Formicodiplogaster myrmenema, carried by Azteca alpha workers in Dominican amber [1] (Figures 23 and 24). The dauer stages appear to be associated with the abdomen of the ants, suggesting that they were being carried in the segmental membranes of the gaster (external phoresis). None of the fossil stages occurred around the mouthparts of the ants. Also, developing stages of F. myrmenema were associated with nest material adjacent to worker Azteca ants in Dominican amber

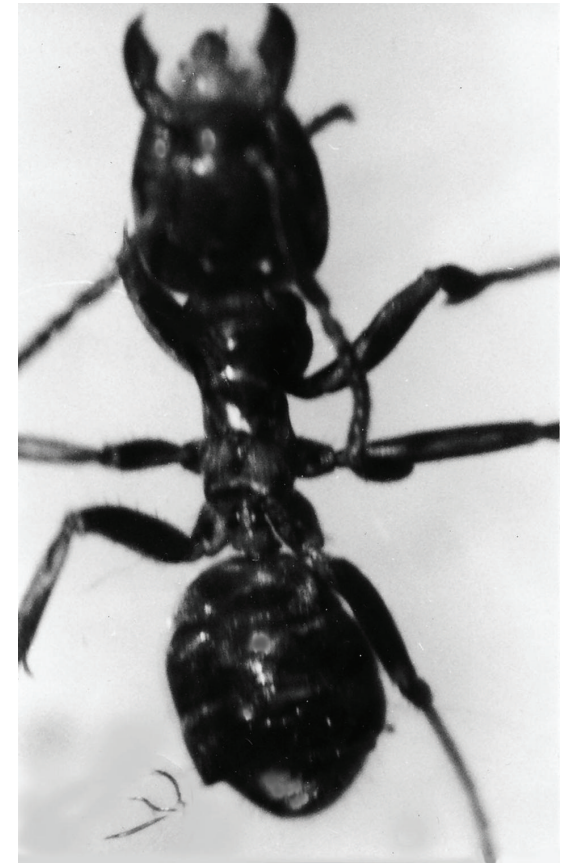

FIgURE 23: Three dauer juveniles of Formicodiplogaster myrmenema adjacent to a worker of Azteca alpha in Dominican amber.

[1]. This indicates that F. myrmenema was developing in the nests of $A$. alpha, which is probably the case with extant nematodes in the head glands of ants. Whether the dauers of F. myrmenema were also in the postpharyngeal glands of the fossil ants is unknown. 
TABle 4: Ants infected by entomopathogenic nematodes (Steinernema carpocapsae and Heterorhabditis bacteriophora) under laboratory and/or field conditions.

\begin{tabular}{lccc}
\hline Ant & Nematode & System & Reference \\
\hline Acromyrmex octospinosus & S. carpocapsae & Aqueous & Sucrose \\
Camponotus sp. & S. carpocapsae & Aqueous & {$[45]$} \\
Camponotus sp. & S. carpocapsae & Aqueous & {$[46]$} \\
Myrmica sp. & S. carpocapsae & Sucrose & {$[47]$} \\
Pogonomyrmex sp. & S. carpocapsae & Alginate capsules \\
Solenopsis spp. & S. carpocapsae & Aqueous & Aqueous \\
Solenopsis geminata & S. carpocapsae & Aqueous & {$[47]$} \\
Solenopsis invicta & S. carpocapsae & Aqueous & {$[48]$} \\
Solenopsis invicta & H. bacteriophora & Aqueous & {$[50,51]$} \\
Solenopsis richteri & H. bacteriophora & {$[52]$} \\
Solenopsis richteri & S. carpocapsae & {$[52]$} \\
\hline
\end{tabular}

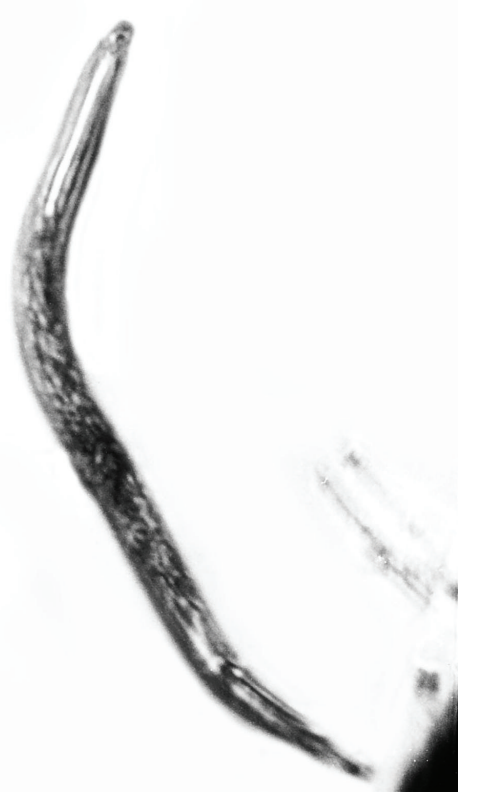

FIGURE 24: Detail of a dauer juvenile of Formicodiplogaster myrmenema adjacent to a worker of Azteca alpha in Dominican amber.

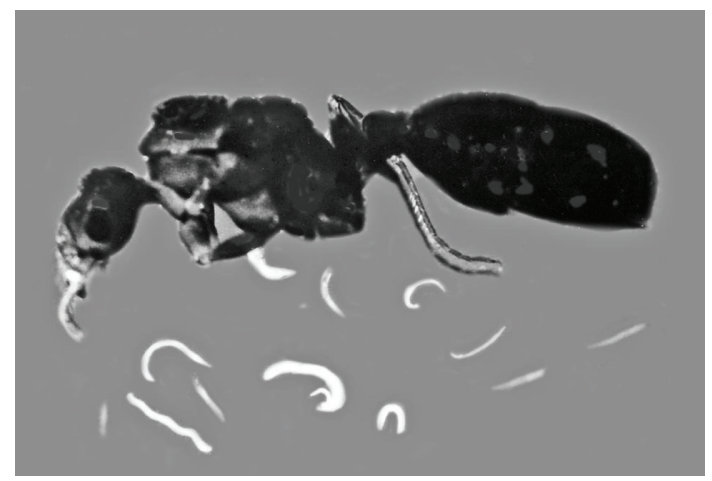

FIGURE 25: Developing stages of Steinernema carpocapsae removed from the body of an infected queen of Solenopsis invicta.

\section{Steinernematidae and Heterorhabditidae}

Included in this section are the so-called entomopathogenic nematodes belonging to the genera Steinernema and Heterorhabditis. It is quite likely that entomopathogenic nematodes infect ants under natural conditions, but no reports are known. Infection is initiated by a third-stage infective juvenile that enters the host's body cavity, apparently per os [50]. After reaching the hemocoel, the infective stage initiates development and, in so doing, releases a symbiotic bacterium (Xenorhabdus spp. in Steinernema nematodes and Photorhabdus spp. in Heterorhabditis nematodes) that is carried in the infective stage's gut lumen. The bacterium kills the insect soon after it is released in the body cavity. The nematodes feed on the mixture of bacteria and insect hemolymph and develop to the adult stage in the body cavity. With adequate nourishment, the nematodes undergo a second generation but when nourishment is limited, the juveniles form third-stage infective juveniles. By introducing the bacteria that quickly kill the hosts, these nematodes avoid specific defense responses and have a wide host range, attacking representatives of many insect orders and even other arthropods [54].

Laboratory experiments have shown that these nematodes can infect a number of ant species (Table 4) and they also have been used in the field against pest ants [50, 52, 5456]. Poole [50] attempted to control field populations of ants (Solenopsis richteri and S. invicta) with Steinernema carpocapsae. Using a dose of 1 million infective stages per mound for S. invicta, the nematodes caused $35 \%$ mortality in the fall and $80 \%$ mortality in the spring. With S. richteri, the death rate was $80 \%$ in the spring and $36 \%$ in the fall. Poole [50] noted that workers were infected less than other stages, possibly because of their greater activity and grooming behavior. However, workers regurgitated infective stages to the alates and larvae. Queen ants were more susceptible and up to 3,000 infective stage juveniles could be produced in some infections (Figure 25).

Further field trials of S. carpocapsae and Heterorhabditis bacteriophora against the red imported fire ant, S. invicta, 
TABle 5

\begin{tabular}{|c|c|c|}
\hline \multirow[t]{2}{*}{ (1) } & $\begin{array}{l}\text { Nematodes represented as dauer or postdauer juveniles in the pharyngeal } \\
\text { glands of ants }\end{array}$ & $\begin{array}{l}\text { Rhabditidae, Diplogastridae and } \\
\text { Panagrolaimidae }\end{array}$ \\
\hline & Nematodes developing in the body cavity of ants & $(2)$ \\
\hline \multirow[t]{2}{*}{ (2) } & Only juvenile nematodes present & (3) \\
\hline & Adult nematodes with or without juveniles & $(4)$ \\
\hline \multirow[t]{2}{*}{ (3) } & $\begin{array}{l}\text { Elongate nematodes normally over } 15 \mathrm{~mm} \text { in length at completion of } \\
\text { development; not enclosed in membranous capsules }\end{array}$ & Mermithidae \\
\hline & Nematodes under $10 \mathrm{~mm}$ in length; enclosed in membranous capsules & Physalopteridae \\
\hline \multirow[t]{2}{*}{ (4) } & Nematodes reproducing in dead ants; infective juveniles produced & $(5)$ \\
\hline & Nematode adults, eggs and/or juveniles in living ants; infective juveniles absent & $(6)$ \\
\hline \multirow[t]{2}{*}{ (5) } & Males with a bursa; females with a pointed tail & Heterorhabditidae \\
\hline & $\begin{array}{l}\text { Males without a bursa; females with a bluntly rounded tail, often bearing a } \\
\text { small point at tip }\end{array}$ & Steinernematidae \\
\hline \multirow[t]{2}{*}{ (6) } & Eggs and juveniles present & Allantonematidae \\
\hline & Eggs, but no juveniles present & (7) \\
\hline \multirow[t]{2}{*}{ (7) } & Vulva positioned at middle or lower half of body & Tetradonematidae \\
\hline & Vulva positioned in upper fourth of body & Seuratidae \\
\hline
\end{tabular}

gave control rates of $37.5 \%$ with S. carpocapsae but less with $H$. bacteriophora [52]. In field trials comparing applications of Steinernema carpocapsae and amidinohydrazone against $S$. invicta, Morris et al. [55] estimated that nematode applications at a rate of 2 million per gallon per mound resulted in $47 \%$ mortality.

Controlling fire ants in the field is difficult because of the small mound opening through which the nematodes are introduced. Also, it is desirable to have recycling of the nematodes in the nests, but healthy ants appear to remove infected individuals before the cycle is completed. Since the number of nematodes needed to overwhelm a colony of ants is quite high using inundative methods, consideration was given to the development of baits or other more efficient delivery systems $[46,48,52,55,56]$. These other methods are still under investigation.

\section{Unknown Nematodes}

Gösswald [57] reported the presence of several encysted nematodes in the flight muscles of a queen Teleutomyrmex schneideri in Germany. The cysts were quite small, being only $25 \mu \mathrm{m}$ in diameter. Except for their small size, the cysts are similar in appearance to those of the vespid mermithid, Pheromermis pachysoma, formed in the body wall of Trichoptera paratenic hosts [27] and the ant parasite, P. villosa, in the body of oligochete paratenic hosts [26]. However, the Pheromermis cysts are $60-100 \mu \mathrm{m}$ and $80 \mu \mathrm{m}$ in diameter, respectively. It is possible that juvenile nematodes of a mermithid parasite were acquired after the queen was fully formed and the nematodes preferred to encyst rather than initiate development. The other likelihood is that the nematodes were the infective stages of a heteroxenous nematode parasite and were waiting for transfer to a vertebrate definitive host. However, the only cysts of heteroxenous nematodes known from ants are those of the physalopterid, S. phryn- osoma, the smallest of which measures $633 \mu \mathrm{m}$ in diameter [39].

In 1907, Janet [58] found nematodes $7-8 \mathrm{~mm}$ in length developing in the head cavities and emerging from the labial region of workers of Formica fusca. Just before the nematodes emerged, the infected ants began trembling and eventually died. The head cavities of infected ants were empty upon nematode exit. This behavior of developing in the head of ants is known for some phorid flies but not for nematodes. Whether this was a mermithid with an unusual developmental location or a heteroxenous nematode using the ant as an intermediate host is unknown.

\section{Identification Key to Nematode Families Associated with Ants}

See Table 5 .

\section{Conclusions}

Representatives of most invertebrate parasitic nematode families attack ants, with the exception of sphaerulariids, entaphelenchids, and oxyurids. While mermithids are the most commonly encountered nematode parasites of ants, the complete life cycle of only a single species is known. The life cycle of ant mermithids can be quite complicated when it involves paratenic hosts living in completely different habitats. Even less is known about the life cycles of other ant parasitic nematodes, certainly not enough to consider using them as biological control agents. While the inundative application of entomopathogenic nematodes (Steinernema and Heterorhabditis) can control ants in isolated colonies, establishing nematodes for the sustained control of ant populations has not been achieved.

There are probably many additional nematode parasites of vertebrates utilizing ants as intermediate hosts. Reptiles, 
mammals, and amphibians eat ants, and it follows that nematodes other than Skrjabinoptera phrynosoma would have devised methods of cycling themselves through ants to reach their definitive hosts. In the mysterious case involving Rabbium paradoxus, the presence of adults of a heteroxenous nematode in an ant raises the question of whether formicids can serve as sole hosts or this is just a case of precocity.

Fossils show that mermithids were infecting ants over 40 million years ago and tetradonematids and allantonematids had established parasitic associations with ants some 20-30 million years ago. Such fossils, which can be used to calibrate molecular clocks, provide minimum dates for the occurrence of nematode lineages and show the antiquity of nematodeant relationships.

\section{Acknowledgments}

The author thanks S. D. Porter, Luc Passera and Stephen P. Yanoviak for supplying photos and Brad Vinson for supplying the queen of Solenopsis invicta infected with Steinernema carpocapsae. Grateful appreciation is extended to Roberta Poinar for commenting on earlier versions of the paper.

\section{References}

[1] G. Poinar Jr., The Evolutionary History of Nematodes, Brill, Leiden, The Netherlands, 2011.

[2] W. Gould, An Account of English Ants, A. Millar, London, UK, 1747.

[3] C. M. Diesing, Systema Helminthum, vol. 2, Vindobonae, Wien, Austria, 1851.

[4] C. T. E. von Siebold, "Über die Fadenwürmer der Insekten," Entomologische Zeitschrift, vol. 4, pp. 78-84, 1843.

[5] W. C. Crawley and H. A. Baylis, "Mermis parasitic on ants of the genus Lasius," Journal of the Royal Microscopical Society, vol. 257, pp. 353-372, 1921.

[6] G. Poinar Jr., R. S. Lane, and G. M. Thomas, "Biology and redescription of Pheromermis pachysoma (V. Linstow) n. gen., n. comb., a parasite of yellowjackets," Nematologia, vol. 22, pp. 360-370, 1976.

[7] I. A. Rubstov, Mermithidae: Classification, Importance and Utilization, Academy of Sciences, Leningrad, Russia, 1978.

[8] A. K. Artyukhovsky, Soil Mermithids; Systematics, Biology and Utilization, Voronezh University, Voronezh, Russia, 1990.

[9] H. Kaiser, "Terrestrial and semiterrestrial Mermithidae," in Manual of Agricultural Nematology, W. R. Nickle, Ed., pp. 899965, Marcel Dekker, New York, NY, USA, 1991.

[10] L. Passera, "Les fourmis hôtes provisoires ou intermédiaires des helminthes," L’Année Biologique, vol. 14, pp. 227-259, 1975.

[11] G. Poinar Jr., J. P. Lachaud, A. Castillo, and F. Infante, "Recent and fossil nematode parasites (Nematoda: Mermithidae) of Neotropical ants," Journal of Invertebrate Pathology, vol. 91, no. 1, pp. 19-26, 2006.

[12] G. Poinar Jr., S. D. Porter, S. Tang, and B. C. Hyman, “Allomermis solenopsi n. sp. (Nematoda: Mermithidae) parasitising the fire ant Solenopsis invicta Buren (Hymenoptera: Formicidae) in Argentina," Systematic Parasitology, vol. 68, no. 2, pp. 115$128,2007$.
[13] G. V. Ipateva, I. N. Pimenova, and F. V. Mukhamedzyanova, "A new nematode genus and species, Camponotimermis bifidus gen. and sp. n., from ants," in Helminthes of Insects, M. D. Sonin, Ed., pp. 80-87, E. J. Brill, Leiden, The Netherlands, 1990.

[14] D. Coman, "Mermithide freatice in fauna Republich Populare Române," Academia Republicii Populare Romîne, Studii şi Cercetãri știint, Serii, vol. 2, pp. 123-152, 1953.

[15] G. Poinar Jr., "First fossil record of nematode parasitism of ants; a 40 million year tale," Parasitology, vol. 125, no. 5, pp. 457-459, 2002.

[16] I. A. Rubstov, "A new species of mermithid from ants," Parazitologiya, vol. 4, pp. 338-341, 1970 (Russian).

[17] H. Kaiser, "Morphologische Analyse des Ameisen-Parasitioden Pheromermis villosa n. sp. (Nematoda, Mermithidae)," Mitteilungen des Naturwissenschaftlichen Vereins fur Steiermark, vol. 116, pp. 269-294, 1986.

[18] W. M. Wheeler, "The parasitic origin of macroergates among ants," The American Naturalist, vol. 35, pp. 877-886, 1901.

[19] A. Vandel, "Modifications déterminées par un Nématode du genre Mermis chez les ouvrières et les soldats de la fourmi Pheidole pallidula (Nyl.)," Bulletin biologique de la France et de la Belgique, vol. 61, pp. 38-47, 1927.

[20] W. M. Wheeler, "Mermis parasitism and intercastes among ants," Journal of Experimental Zoology, vol. 50, pp. 165-237, 1928.

[21] K. Gösswald, "Weitere Beiträge zur Verbreitung der Mermithiden bei Ameisen," Zoologischer Anzeiger, vol. 90, pp. 13-27, 1930.

[22] K. Gösswald, "Über bisher unbekannte, durch den Parasitismus der Mermithiden (Nemat.) verursachte Formveränderungen bei Ameisen," Zeitschrift für Parasitenkunde, vol. 10, no. 1, pp. 138-152, 1938.

[23] L. Passera, "Présence d'Hexamermis sp. (Nematoda, Mermithidae) dans les reines vierges et les mâles de la fourmi Pheidole pallidula Nyl. (Formicidae, Myrmicinae)," Bulletin de la Société Zoologique de France, vol. 99, pp. 315-324, 1974.

[24] L. Passera, "Origine des intercastes dans les sociétés de Pheidole pallidula (Nyl.) (Hymenoptera Formicidae) parasitées par Mermis sp. (Nematoda Mermithidae)," Insectes Sociaux, vol. 23, no. 4, pp. 559-575, 1976.

[25] A. Vandel, "Le cycle évolutif d'Hexamermis sp. parasite de la fourmi (Pheidole pallidula)," Annales des Sciences Naturelles, vol. 17, pp. 47-58, 1934.

[26] H. Kaiser, "Über Wechselbeziehungen zwischen Nematoden (Mermithidae) und Ameisen," Zoologischer Anzeiger, vol. 217, pp. 156-177, 1986.

[27] G. Poinar Jr., "Distribution of Pheromermis pachysoma (Mermithidae) determined by paratenic invertebrate hosts," Journal of Nematology, vol. 13, pp. 421-424, 1981.

[28] G. Steiner, "A remarkable new genus and species of mermithid worms from Jamaica," Proceedings of the United States National Museum, vol. 65, pp. 1-4, 1924.

[29] D. A. McInnes and W. R. Tschinkel, "Mermithid nematode parasitism of Solenopeis ants (Hymenoptera: Formicidae) of northern Florida," Annals of the Entomological Society of America, vol. 89, no. 2, pp. 231-237, 1996.

[30] D. P. Jouvenaz and D. P. Wojcik, "Parasitic nematode observed in the fire ant, Solenopsis richteri, in Argentina," The Florida Entomologist, vol. 73, pp. 674-675, 1990.

[31] W. R. Nickle and D. P. Jouvenaz, "Tetradonema solenopsis n. sp. (Nematoda: Tetradonematidae) parasitic on the red imported fire ant Solenopsis invicta Buren from Brazil," Journal of Nematology, vol. 19, pp. 311-313, 1987. 
[32] G. Poinar Jr. and S. P. Yanoviak, "Myrmeconema neotropicum n. g., n. sp., a new tetradonematid nematode parasitising South American populations of Cephalotes atratus (Hymenoptera: Formicidae), with the discovery of an apparent parasiteinduced host morph," Systematic Parasitology, vol. 69, no. 2, pp. 145-153, 2008.

[33] S. P. Yanoviak, M. Kaspari, R. Dudley, and G. Poinar Jr., "Parasite-induced fruit mimicry in a tropical canopy ant," The American Naturalist, vol. 171, no. 4, pp. 536-544, 2008.

[34] G. Poinar Jr., "Formicitylenchus oregonensis n. g., n. sp. (Allantonematidae: Nematoda), the first tylenchid parasite of ants, with a review of nematodes described from ants," Systematic Parasitology, vol. 56, no. 1, pp. 69-76, 2003.

[35] W. P. Rogers, The Nature of Parasitism, Academic Press, New York, NY, USA, 1962.

[36] G. Poinar Jr., A. G. Chabaud, and O. Bain, "Rabbium paradoxus sp. n. (Seuratidae: Skrjabinelazienae) maturing in Camponotus castaneus (Hymenoptera: Forimicidae)," Proceedings of the Helminthological Society of Washington, vol. 56, pp. 120 124, 1989.

[37] A. G. Chabaud, O. Bain, and G. Poinar Jr., "Skrjabinelazia galliardi (Nematoda, Seuratoidea): compléments morphologiques et cycle biologique," Annales de Parasitologie, vol. 63, no. 4, pp. 278-284, 1988.

[38] M. B. Chitwood, "A new spiruroid nematode, Rabbium caballeroi, from the stomach of Leiocephalus carinatus, from the Bahama Islands," in Libro Homenaje al Doctor Eduardo Caballero y Caballero, pp. 471-473, Secretaria de Educacion Publica, Mexico City, Mexico, 1960.

[39] S. H. Lee, "The life cycle of Skrjabinoptera phrynosoma (Ortlepp) Schulz, 1927 (Nematoda: Spiruroidea), a gastric nematode of Texas horned toads, Phrynosoma cornutum," The Journal of parasitology, vol. 43, no. 1, pp. 66-75, 1957.

[40] G. P. Markin and C. W. McCoy, "The occurrence of a nematode, Diploscapter lycostoma, in the pharyngeal glands of the Argentine Ant, Iridomyrmex humilis," Annals of the Entomological Society of America, vol. 61, pp. 505-509, 1968.

[41] A. Köhler, "Nematodes in the heads of ants associated with sap flux and rotten wood," Nematology. In press.

[42] A. Wahab, "Untersuchungen über Nematoden in den drüsen des kopfes der Ameisen (Formicidae)," Zeitschrift für Morphologie und Ökologie der Tiere, vol. 52, no. 1, pp. 33-92, 1962.

[43] M.-Ch. Janet, "Sur les nématodes des glandes pharyngiennes des fourmis (Pelodera sp.)," Comptes Rendus de l'Academie des Sciences, vol. 117, pp. 700-703, 1893.

[44] W. R. Nickle and G. L. Ayre, "Caenorhabditis dolichura (A. Schneider, 1866) Dougherty (Rhabditidae, Nematoda) in the head glands of the ants Camponotus herculeanus (L.) and Acanthomyops claviger (Roger) in Ontario," Proceedings of the Entomological Society of Ontario, vol. 96, pp. 96-98, 1966.

[45] A. Kermarrec, "Étude des relations synécologiques entre les nématodes et la fourmi-manioc: Acromyrmex octospinosus Reich," Annales de Zoologie-Ecologie Animale, vol. 7, pp. 2744, 1975.

[46] R. Georgis and G. Poinar Jr., "Field effectiveness of entomophilic nematodes Neoaplectana and Heterorhabditis," in Integrated Pest Management for Turfgrass and Ornamentals, A. R. Leslie and R. L. Metcalf, Eds., pp. 213-224, United States Environmental Protection Agency Publication, Government Printing Office, Washington, DC, USA, 1989.

[47] R. A. Bedding, "Nematode parasites of Hymenoptera," in Plant and Insect Nematodes, W. R. Nickle, Ed., pp. 755-795, Marcel Dekker, New York, NY, USA, 1984.
[48] R. Georgis, "Nematodes for biological control of urban insects," Proceedings of the American Chemical Society; Division of Environmental Chemicals, vol. 27, pp. 816-821, 1987.

[49] A. Kermarrec, G. Febvay, and M. Decharme, "Protection of leaf-cutting ants from biohazards: is there a future for microbiological control?" in Fire Ants and Leaf-Cutting Ants, C. S. Lofgren and R. K. van der Meer, Eds., pp. 339-356, Westview Press, Boulder, Colo, USA, 1986.

[50] M. A. Poole, Survey and control efficacy of endoparasites of Solenopsis richteri Forel and Solenopsis invicta Buren in Mississippi, Ph.D. dissertation, Mississippi State University, Mississippi State, Miss, USA, 1976.

[51] C. S. Lofgren, W. A. Banks, and B. M. Glancey, "Biology and control of imported fire ants," Annual Review of Entomology, vol. 20, pp. 1-30, 1975.

[52] E. D. Quattlebaum, Evaluation of fungal and nematode pathogens to control the red imported fire ant, Solenopsis invicta Buren, Ph.D. dissertation, Clemson University, Clemson, SC, USA, 1980.

[53] H. Naarmann, "Untersuchungen über Bildung und Weitergabe von Drüsensekreten bei Formica (Hymenopt. Formicidae) mit Hilfe der Radioisotopenmethode," Experientia, vol. 19, no. 8, pp. 412-413, 1963.

[54] G. Poinar Jr., Nematodes for Biological Control of Insects, CRC Press, Boca Raton, Fla, USA, 1979.

[55] J. R. Morris, K. W. Stewart, and R. L. Hassage, "Use of the nematode Steinernema carpocapsae for control of the red imported fire ant (Hymenoptera: Formicidae)," The Florida Entomologist, vol. 73, pp. 675-677, 1990.

[56] G. Poinar Jr. and R. Georgis, "Biological control of social insects with nematodes," in Integrated Pest Management for Turfgrass and Ornamentals, A. R. Leslie and R. L. Metcalf, Eds., pp. 255-269, United States Environmental Protection Agency Publication, Government Printing Office, Washington, DC, USA, 1989.

[57] K. Gösswald, "Histologische Untersuchungen an der arbeiterlosen Ameise Teleutomyrmex schneideri Kutter (Hym. Formicidae)," Mitteilungen der Schweizerischen Entomologischen Gesellschaft, vol. 26, pp. 81-128, 1953.

[58] M.-Ch. Janet, "Sur un Nématode qui se développe dans la tête de la Formica fusca," Mémoires de la Société Académique d'Archéologie, sciences et Arts du Département de l'Oise, vol. 20, pp. 1072-1073, 1907. 

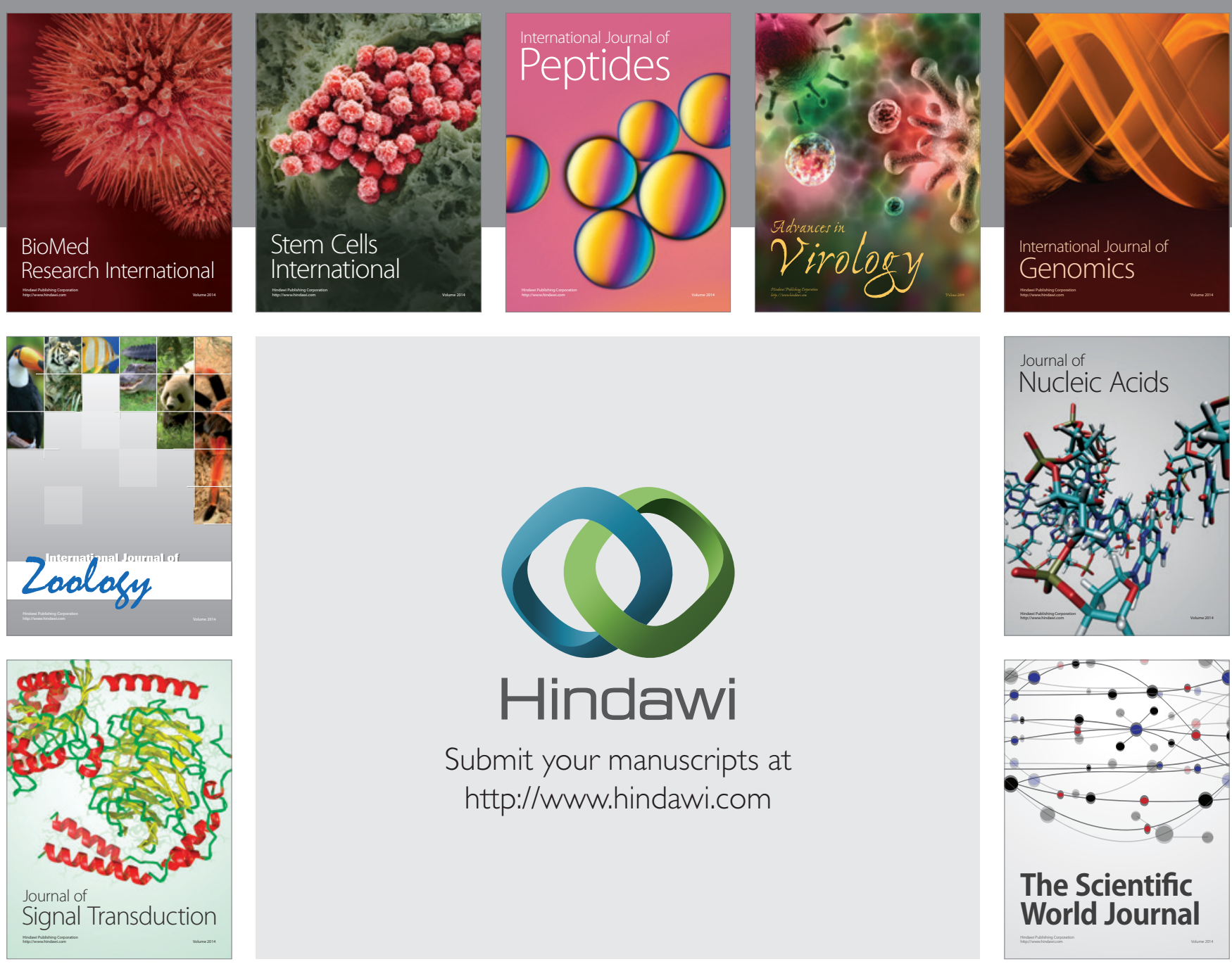

Submit your manuscripts at

http://www.hindawi.com
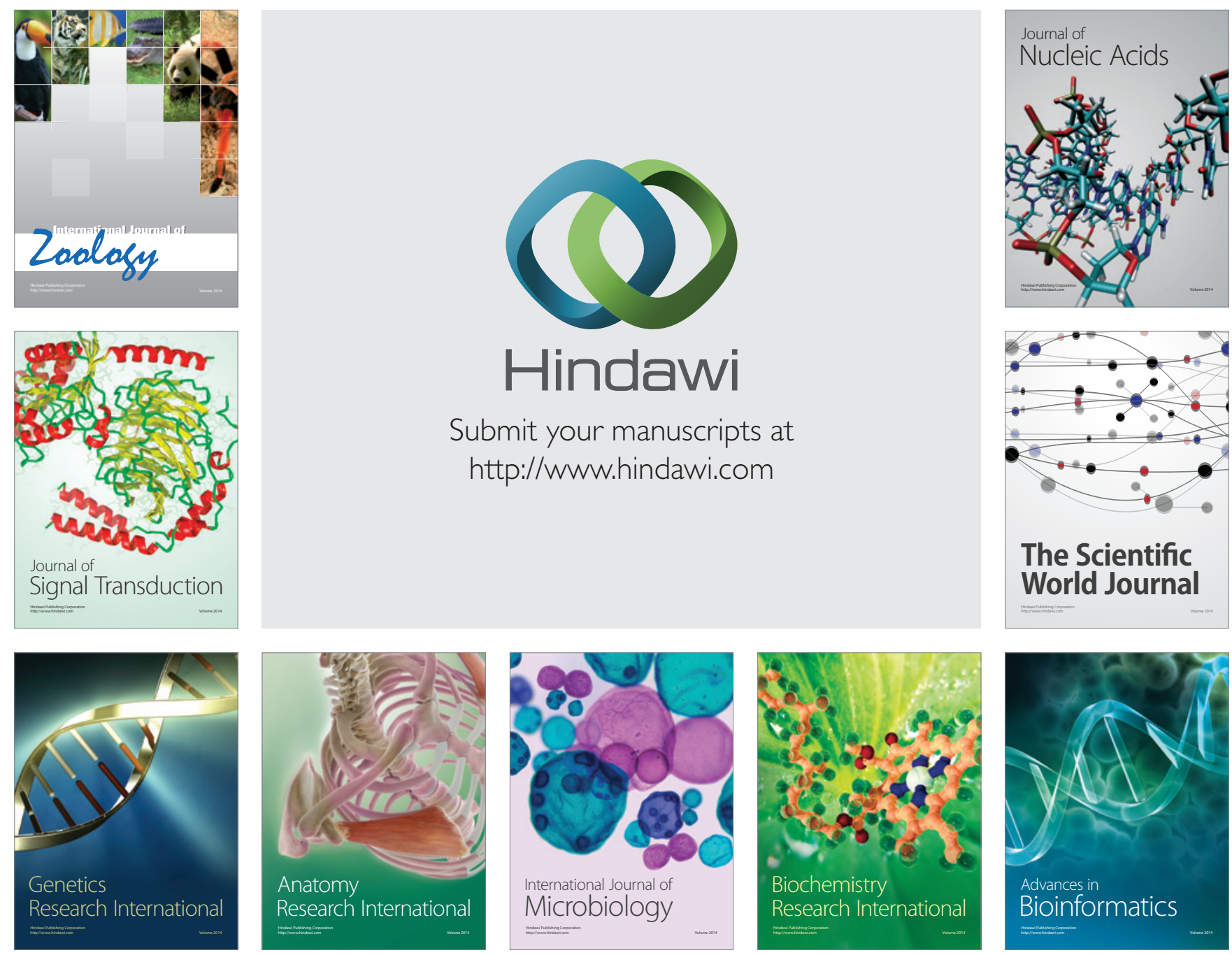

The Scientific World Journal
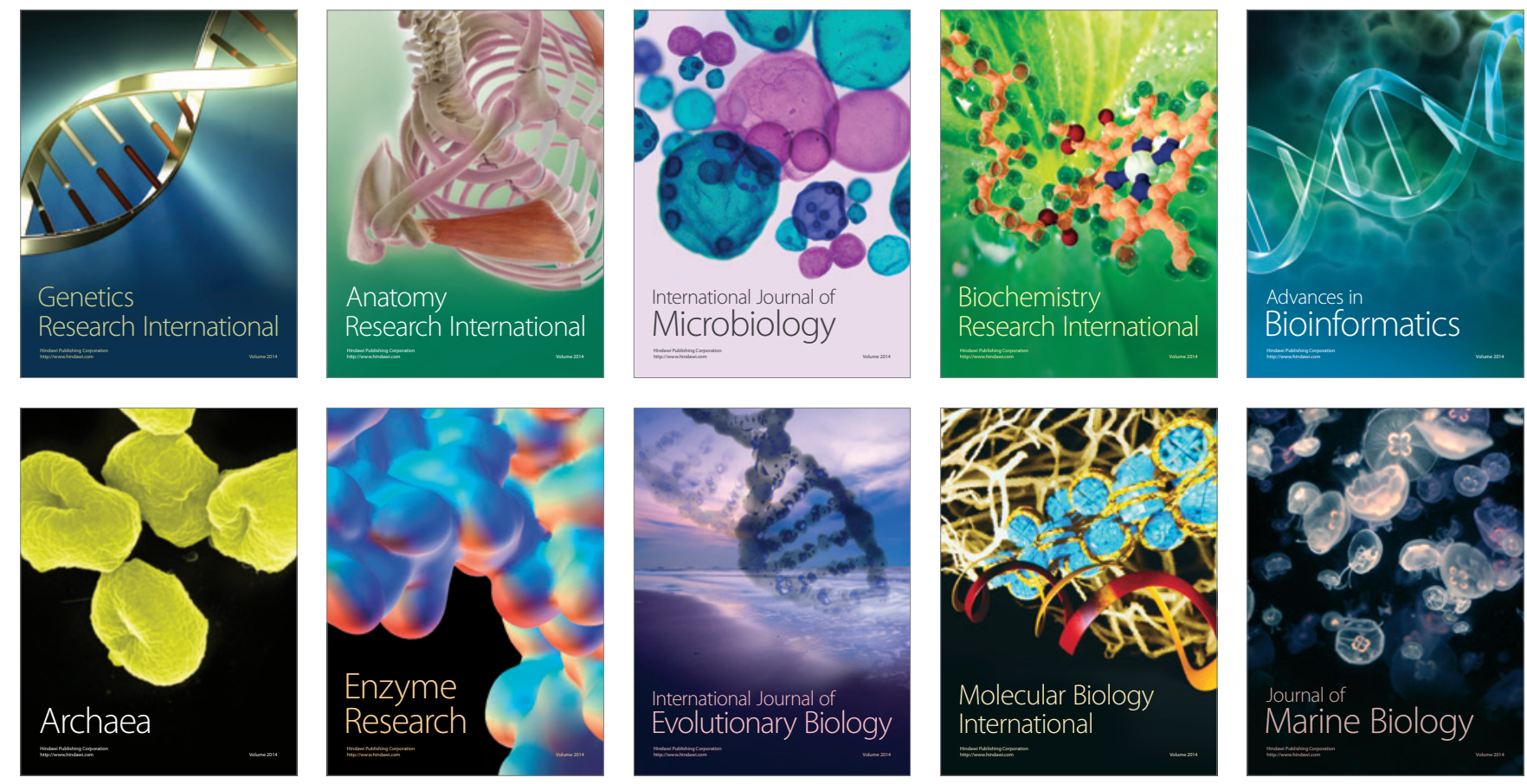